\title{
Domestication and Formulation of Rhizopodopsis javensis as a Tempeh Starter
}

\author{
GAYUH RAHAYU ${ }^{1} *$, EFRIWATI ${ }^{2}$, AND SEPTINA VERONICA ${ }^{1}$ \\ 'Department of Biology, Faculty of Mathematics and Natural Sciences, Institut Pertanian Bogor, \\ Darmaga Campus, Bogor 16680, Indonesia; \\ ${ }^{2}$ The Biomedical and Basic Health Technology Research and Development Centre National Institute of Health Research \\ and Development Ministry of Health Republic of Indonesia, Jakarta 10560, Indonesia.
}

\begin{abstract}
Domestication of wild fungal strains involved in the manufacture of traditional fermented foods often occurs spontaneously. Rhizopodopsis javensis (Rh. javensis) which taxonomically close to Rhizopus is a fungus type naturally found in cool climates, and promisingly can be used as a tempeh starter in temperate regions. However before using it as starter, a Rh. javensis wild strain needs to be domesticated in human-made niches. At present study, this species was domesticated by subculture using rice flour media at optimum growth temperature for every five days. Some parameters such as spore's density, viability, and starter water content were used to determine the successfully of domestication. The result showed that $R h$. javensis grew optimally at $22{ }^{\circ} \mathrm{C}$. Moreover, it has been reproducible for seven times which indicated by no changes in growing rate and colony appearance. However, compared to the commercial tempeh starter and R. microsporus var. oligosporus wild type, it has lower spore's viability with higher water content. Therefore, the carrier material and other parameters such as drying processes and starter's lifespan need to be modified to increase the spore viability and starter quality.
\end{abstract}

Key words: food fermentation, Rhizopus microsporus var. oligosporus, spore's viability, starter quality, wild strain

Domestikasi galur liar kapang yang terlibat dalam dalam pembuatan makanan fermentasi tradisional, sering terjadi secara spontan. Rhizopodopsis javensis (Rh. javensis) merupakan salah satu galur liar kapang yang memiliki hubungan taksonomi dekat dengan Rhizopus. Strain liar ini ditemukan di daerah beriklim sejuk, sehingga berpotensi untuk dikembangkan sebagai starter tempe untuk produksi di daerah beriklim sedang. Untuk mendapatkan kultur yang tumbuh subur di relung (niches) buatan manusia, strain liar Rh. javensis perlu didomestikasi terlebih dahulu. Penelitian ini bertujuan untuk mendomestikasi strain Rh. javensis liar yang dilanjutkan dengan memformulasikannya sebagai starter tempe. Domestikasi dilakukan dengan menumbuhkan strain liar Rh.javensis pada media tepung beras pada suhu pertumbuhan optimum dan diulangi setiap lima hari. Kerapatan dan viabilitas spora, serta kadar air starter digunakan sebagai penilaian keberhasilan starter. Hasil penelitian menemukan Rh. javensis tumbuh optimal pada suhu $22^{\circ} \mathrm{C}$. Domestikasi dengan cara subkultur koloni Rh. javensis pada media tepung beras selama 7 kali tidak mengubah kecepatan pertumbuhan Rh. javensis dan penampakan koloni. Laju pertumbuhan Rh. javensis relatif sama dengan laju pertumbuhan starter tempe komersial dan $R$. microsporus var. oligosporus murni, pada suhu optimum pertumbuhan masing-masing. Formulasi tepung beras sebagai media pembawa starter Rh. javensis, menghasilkan kerapatan spora yang relatif sama dengan starter tempe komersial, namun viabilitas sporanya rendah dan kadar airnya tinggi. Starter $R h$. javensis belum dapat digunakan untuk membuat tempe. Substrat dan proses pengeringan masih perlu dimodifikasi untuk meningkatkan viabilitas spora dan kualitas starter tempe secara keseluruhan, termasuk umur simpan starter.

Kata kunci: fermentasi makanan, kualitas starter, Rhizopus microsporus var. oligosporus, strain liar, viabilitas spora

Tempeh is made from soybean fermented by the microbial community. Although Rhizopus sp. is the only microbe that is deliberately given as the tempeh starter, Lactic Acid Bacteria (LAB) and other types of bacteria (Seumahu et al. 2013, Efriwati et al. 2013), and yeast (Efriwati et al. 2013) were found during tempeh making process. Rhizopus microsporus, $R$. rhizopodiformis, $R$. chinensis, $R$. arrhizus, and $R$.

*Corresponding author: Phone: +62-816-1133-725 ; Fax: +62;E-mail: gayuhrahayu@gmail.com stolonifer were often found in Indonesian traditionally tempeh-making processes (Tamam et al. 2019, Putri et al. 2021). Furthermore, R. microsporus var. oligosporus and $R$. oryzae were often used as commercial tempeh starters (Ahnan-Winarno et al. 2021). With the increasing preference of the Indonesian people to use a specific commercial starter, the diversity of Rhizopus species in tempeh decreases (Hartanti et al. 2015). Rhizopus delemar, which previously reported as $R$. oryzae, was no longer found in all fresh tempeh from Java island (Hartanti et al. 2015). In contrast, Barus et 
al. (2019) stated that two strains of $R$. delemar obtained from Waru (Hibiscus tiliaceus) leaves produced a better tempeh taste and more preferred than usual tempeh. Therefore, it is necessary to preserve various Rhizopus species from tempeh, including exploring new Rhizopus species or their close relatives for obtainig new potential strains for tempeh production.

Domestication of microbial agents for food fermentation is defined as human selection to obtain cultivated strains that grow well in man-made environments, but may behave sub optimally in nature (Gallone et al. 2016). Tempeh starters should include only food-grade microbes. Rhizopus microsporus var. oligosporus has not been found in nature (Dolatabali et al. 2013) and did not produce harmful metabolite (Ahnan-Winarno et al. 2021). Dolatabali et al. (2013) suggseted that $R$. microsporus var. oligosporus might become from the domestication of $R$. microsporus. Domestication increases $R$. microsporus functionality for humans. It also ensures food quality, homogeneity, and food safety (Gibbons and Rinker 2015). This domestication process occurs due to cultivating the mold in an isolated environment from its ancestor population to increase specific function for a human being (Gallone et al. 2020). In traditional fermented food, domestication might be due to back slopping (Wijaya et al. 2015, Gallone et al. 2020).

Rhizopus oligosporus are cultivated during tempeh production, and this mold grow optimum at $30-37^{\circ} \mathrm{C}$ (Tahir et al. 2018). Tempeh production in other countries with the same climate as Indonesia (tropical) was easy to be done, but not in countries with a subtropical climate. Within their study, Ahnan-Winarno et al. (2021) described tempeh production in the subtropical region was more challenging. Hence, it is necessary to search for alternative molds for subtropical regions.

Rhizopodopsis javensis is a Mucorales that is expected to be able to grow at low temperature (around $20^{\circ} \mathrm{C}$ ) as that mold has been found in mountain areas (Cibodas, Cianjur, West Java). Thus, Rh. javensis can probably be developed as a starter to produce tempeh in the subtropical region. However, domestication of $R h$. javensis as artificial selection and wild species culturing must be done prior to making it a tempeh starter. Domestication is needed to obtain variants that thrive in human-made niches to meet human or industrial needs (Steensels et al. 2019). According to Pramudito et al. (2021), rice is usually made as a carrier material in tempeh starter. This research aimed to domesticate the wild strain of $R h$. javensis and followed by the formulation of domesticated strain as a tempeh starter. The domesticated strain is expected to meet the criteria for tempeh starter, which was determined based on spore density and viability, as well as starter physical characteristics such as water content.

\section{MATERIALS AND METHODS}

Microbial Strains and Media. Rhizopodopsis javensis IPBCC 19.1478, Rhizopus microsporus var. oligosporus IPBCC 13.1102, and commercial tempeh starter (Raprima $\left.{ }^{\circledR}\right)$ were used in this research. Rice flour from rice var. IR 64 Setra Ramos was used as $R h$. javensis domestication media. Potato Dextrose Agar (PDA) was used as media for mold sub-culturing. Working culture of Rh. javensis and R. microsporus var. oligosporus were obtained by rejuvenating stock culture on PDA media and incubated for 2-7 days in 19$23^{\circ} \mathrm{C}$ for Rh. javensis and in $32^{\circ} \mathrm{C}$ for $R$. microsporus var. oligosporus.

Microbial Domestication. Prior to domestication, $R h$. javensis optimum growth temperature was determined. This experiment was done by growing two-day-old culture on PDA and incubating them at 20, $22,24,26,28$, and $30^{\circ} \mathrm{C}$. The experiment was done in 3 replicates. The colony diameter was measured every 6 hours until the colony entirely covered the media in all the Petri dishes. The growth and the sporulation rate determined the optimum growth temperature. The optimum temperature obtained was then used for $R h$. javensis domestication process on the tempeh starter carrier.

Rhizopodopsis javensis was domesticated on $50 \mathrm{gr}$ sterile rice flour that was wetted by $15 \mathrm{~mL}$ sterilized water. A few pieces of Rh. javensis inocula $( \pm 5 \mathrm{~mm}$ diameter) were cultured on rice flour media and incubated at $R h$. javensis optimum growth temperature for five days. This sub-culturing was done up to seven times. The colonies that grew from the last subculturing were regrown on PDA to evaluate their domestication growth capability. The colony characteristics and the growth rate before and after domestication were then compared.

The domesticated $R h$. javensis strain that showed comparable characters were used as materials to make starters. The inoculum, for starters, was produced in a similar procedure to that of the domestication. After five days of incubation, that culture was made into powder and dried at $30{ }^{\circ} \mathrm{C}$ for two days. These processes were also done to $R$. microsporus var. oligosporus and the wild strain of $R h$. javensis for 
Table 1 Density and viability of spores of various molds in the starter

\begin{tabular}{lccc}
\hline \multicolumn{1}{c}{ Starter type } & $\begin{array}{c}\text { Spore density } \\
\text { Log spore/g }\end{array}$ & $\begin{array}{c}\text { Number of colonies } \\
\text { Log cfu/g }\end{array}$ & $\begin{array}{c}\text { Spore viability } \\
(\%)\end{array}$ \\
\hline Rh. javensis wild type & $6.23 \pm 0.39$ & $4.06 \pm 0.30$ & $0.67^{\mathrm{a}}$ \\
Rh. javensis domesticated type & $6.75 \pm 0.22$ & $3.88 \pm 0.30$ & $0.13^{\mathrm{a}}$ \\
R. microsporus var. oligosporus & $6.89 \pm 0.15$ & $4.38 \pm 0.43$ & $0.31^{\mathrm{a}}$ \\
Raprima & $6.51 \pm 0.20$ & $4.82 \pm 0.03$ & $2.03^{\mathrm{a}}$ \\
\hline
\end{tabular}

Table 2 Water content during fermentation from several type of tempeh starter

\begin{tabular}{lc}
\hline \multicolumn{1}{c}{ Starter Type } & Water Content $(\%)$ \\
\hline Rh. javensis wild type & $10.58 \pm 1.08^{\mathrm{a}}$ \\
Rh. javensis domesticated type & $10.08 \pm 1.17^{\mathrm{a}}$ \\
R. microsporus var. oligosporus & $9.08 \pm 1.59^{\mathrm{a}}$ \\
Raprima & $8.00 \pm 0.29^{\mathrm{a}}$ \\
\hline
\end{tabular}

comparison.

Spore density was determined by observing the suspension of diluted starter in a hemocytometer counting chamber. Spore viability was determined by using the spread plate method with three replicates. The water content was determined using the oven method, according to SNI 01-2891-1992. The density and viability of $R h$. javensis spore and the starter's water content were compared with the density and viability and water content of $R$. microsporus var. oligosporus and commercial starters.

The Kruskal-Wallis test analyzes the differences within optimum growth temperature and spore viability, with 0.05 probability. Colony growth data of $R h$. javensis, R. microsporus var. oligosporus, and Rhizopus in the commercial starter, Raprima ${ }^{\circledR}$, were analyzed using the Brown-Forsythe test; meanwhile, data on spore density and starter water content were analyzed one-way ANOVA with a $95 \%$ confidence level. The $R h$. javensis optimum growth temperature determination with distinctly different results was analyzed using the Mann-Whitney test at $\alpha=0.05$. All data were analyzed using SPSS (Statistical Package for the Social Science) software 16.00 version.

\section{RESULT}

The temperature affected $R h$. javensis growth, as seen from the colony's diameter (Fig 1 and 2). The optimum growth temperature for $R h$. javensis was about $22{ }^{\circ} \mathrm{C}$. At this temperature, $R h$. javensis grew at the maximum rate (Fig $2 \mathrm{~b}$ ). At $28^{\circ} \mathrm{C}$, the growth was sustained, while at $30^{\circ} \mathrm{C}$ there was no growth (Fig 1). The growth rate of domesticated $R h$. javensis was not significantly different from that of the wild type (Fig 3).
Further, $R h$. javensis growth rate was not significantly different from $R$. microsporus var. oligosporus when all were grown at their optimum growth temperatures (Fig 3).

Domestication did not change the characteristics of Rh.javensis. The spore density in $1 \mathrm{~g}$ starter on both the wild and domesticated Rh. javensis starters were relatively the same with spore concentration in commercial tempeh starter and $R$. microsporus var. oligosporus. This research found that all dried starters contained insignificantly different concentration of spore i.e about $10^{6}$ spore/g (Table 1). However, spore viability in all starters was low, only $10^{4} \mathrm{cfu} / \mathrm{g}$ or around $0.13-2.03 \%$ (Table 1 ).

The water content of all starters made in this study was from 8 to $10.58 \%$. The water content of $R h$. javensis and $R$. microsporus var. oligosporus starter was higher but insignificantly different from that of the commercial tempeh starter (Table 2).

\section{DISCUSSION}

In terms of growth in its optimum temperature, $R h$. javensis produced comparable characters to the commercial starter. Rhizopodopsis javensis grew optimally and sporulated well at $22{ }^{\circ} \mathrm{C}$, thus classified as either facultative psychrophilic or psychrotolerant fungi. Psychrotolerant microbes are mesophilic microbes that are cold-tolerant and thrive in an extensive temperature range, with the fastest growth at temperatures above $20{ }^{\circ} \mathrm{C}$. The growth rate of domesticated Rh.javensis, at its optimum temperature, was not significantly different from its original culture (Fig 3). These showed that Rh. javensis was able to adapt to rice flour media. However, Rh. javensis is 


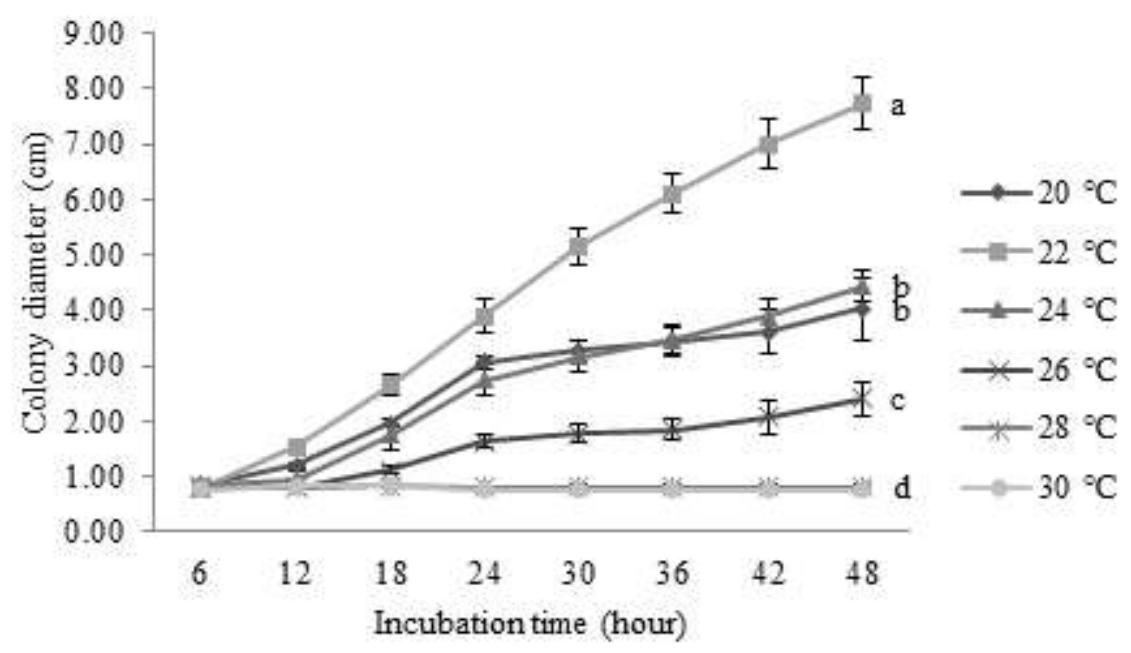

Fig 1 Rhizopodopsis Javensis growth curve at various temperatures during 48 hours incubation. Vertical lines on every data show the standard error. Alphabets at the right show a significant difference of average colony diameter on each temperature according to the Mann-Whitney test at $\alpha=0.05$.

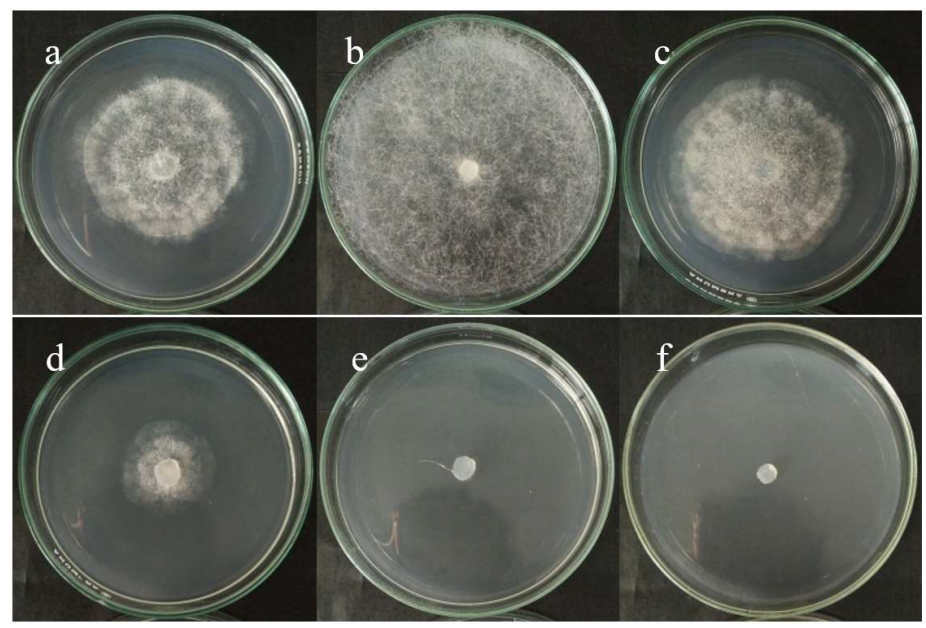

Fig 2 Rhizopodopsis javensis growth after $48 \mathrm{~h}$ incubation on PDA media at (a) $20^{\circ} \mathrm{C}$, (b) $22^{\circ} \mathrm{C}$ (c) $24^{\circ} \mathrm{C}$, (d) $26^{\circ} \mathrm{C}$, (e) $28^{\circ} \mathrm{C}$, and (f) $30^{\circ} \mathrm{C}$.

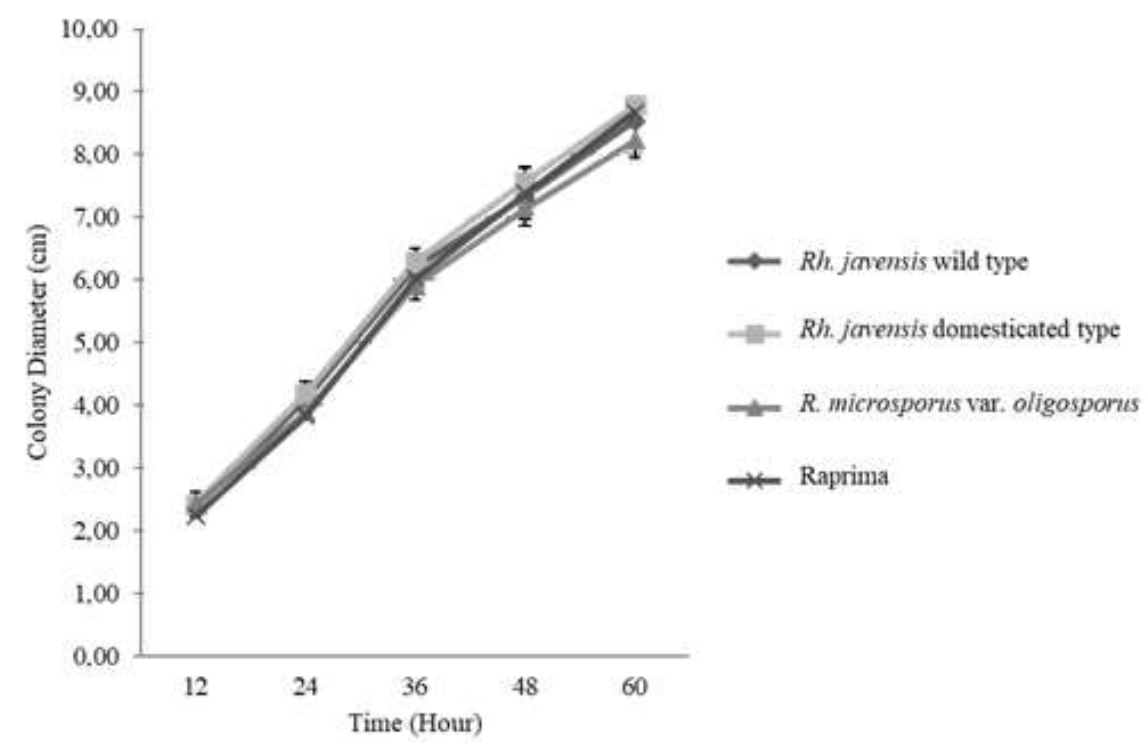

Fig 3 The growth rate of Rh. javensis, R. microsporus var. oligosporus, and Rhizopus in Raprima on PDA media during $60 \mathrm{~h}$ incubation at each optimum temperature. 
naturally found on ripe Elaeagnus and Ficus fruit (Boedijn 1958; Rahayu et al., unpublished).

Further, Rh. javensis growth was not significantly different from $R$. microsporus var. oligosporus and commercial starter Rhizopus (Raprima ${ }^{\circledR}$ ) at their optimum growth temperature. Thus, it is suggested that the starter made from $R h$. javensis could produce tempeh by bringing up the hyphal mass in the same compactness and times as a commercial starter. The commercial tempeh starter requires a temperature of 32 ${ }^{\circ} \mathrm{C}$ to be applied, making it challenging to use in subtropical regions (Samson et al. 2007). Therefore, $R h$. javensis that grow optimum at $22{ }^{\circ} \mathrm{C}$ has an opportunity to be developed as a tempeh starter for tempeh production in regions with a temperature of 22 ${ }^{\circ} \mathrm{C}$ or regions with a subtropical climate.

Domestication would depend on the media used. $R h$.javensis that was domesticated on rice flour media could grow well. Colonization can be observed after three days of incubation. Wijaya et al. (2015) stated that the starter is usually produced by inoculating starter powder from the previous batch to the new rice flour dough which is called as back-slopping (Gallon et al. 2020). Cultivation or sub-culturing that was done continuously in the human-related environment causes microbes to adapt and be more beneficial to humans. The adaptation process caused the morphological and physiological change; therefore, domesticated microbes were different from their wild type. Domestication through the fermentation food process could change organisms genetically and phenotypically (Steensels et al. 2019). However, domesticated Rh.javensis growth and colony color had no difference from its original culture. Rh. javensis that had been sub-cultured continuously had a growth rate that was also relatively the same as its wild type culture (Fig 2).

Besides being a medium for growth, rice flour has functioned as a carrier in starter formulation. Starter carriers could also come from a mixture of rice flour and cassava flour (Ahnan-Winarno et al. 2021, Pramudito et al. 2021). The addition of spices such as garlic or pepper traditionally used in some fermentation starter was not done in this research. The drying process in this research was not conditioned in a very sterile place. It was just prepared like a household scale fermentation. Spices as a natural anti-microbe need to be considered in household-scale starter production as garlic and pepper were known as having anti-microbial and anti-fungal properties (Liu et al. 2017).
Non-domesticated Rh. javensis tempeh starter had moderate hyphae growth, mild alcohol aroma, white or white with black spot, and hyphae bound rice granules firmly (Maulana 2019). The starter must contain high spores or other propagules concentration. In this research, $R$. microsporus var. oligosporus and $R h$. javensis in the starter had relatively the same spore density (Table 1). However, Rh. javensis starter had low spore viability. Thanh and Nout (2007) and Putri et al. (2021) stated that spores viability may reduce by long storage. Furthermore, Putri et al. (2021) stated that high viability spores in starter are needed to ensure successful tempeh fermentation. Low viability is presumed caused by the drying and flouring process. Spore harvesting time, drying, and crushing are factors that cause of spore viability loss (Thanh and Nout 2002).

Rhizopodopsis javensis tempeh starter does not meet the quality of commercial starter. It has a lower concentration of viable spore compared to the commercial starter (Raprima $\left.{ }^{\circledR}\right)$. Thus, the viable spore concentration does not meet the required amount of viable spore of a commercial starter in tempeh production from $1 \mathrm{~kg}$ of soybean. Further, the water content is also still high (Table 2). In a low water content starter, a fermentation agent's metabolic processes will slow down, thus maintaining cell structure and function during storage (Santivarangkna et al. 2008). Some starters containing Rhizopus inoculum for rice wine production must have a moisture content of $4-5 \%$ or $7.8 \%$ (Dung and Phong 2011), while the water content of starter tempeh is about $4-5 . \%$ to $7.5 \%$ (Thanh and Nout 2002). The water content of the starter having $R$ h. javensis was still high, indicating that the drying process was not optimal. The drying process at $30^{\circ} \mathrm{C}$ for 48 hours in this study has not reached the appropriate moisture content. Therefore, the drying method still needs to be modified. These characteristics indicate that the $R h$. javensis starter has low quality and thus cannot be used in the making tempeh trial.

In conclusion, $R h$. javensis grew optimally at 22 ${ }^{\circ} \mathrm{C}$. The domestication using rice flour media with seven times subcultures did not change $R h$. javensis growth rate and its colony characteristics. In the formulation of Rh. javensis starter using rice flour as a carrier resulted in its spore density relatively the same as commercial tempeh starter, but with lower spore viability and higher water content. The quality of $R h$. javensis starter could not be used for tempeh production in sub-tropical climate regions yet. 
Preliminary study on tempeh production using nondomesticated $R h$. javensis starter indicated that $R h$. javensis can be used for tempeh production (Maulana 2019). Tempeh production using non-domesticated $R h$. javensis needs a longer incubation period comparing to that of commercial starter. This indicate that a robust and high concentration of viable spores is needed to shorten the incubation periods. Therefore, domestication of $R h$. javensis to carrier substrate has to be studied further for commercialization. Substrates used, adaptation method and drying process in starter production need to be modified to increase spore viability and overall starter quality, including starter lifespan.

\section{ACKNOWLEDGEMENTS}

We are highly grateful to the Department of Biology IPB University and the Laboratory Chemicals and the Biomedical and Basic Health Technology Research and Development Centre for support throughout the research.

\section{REFERENCES}

Ahnan-Winarno AD, Cordeiro L, Winarno FG, Gibbons J, Xiao H. 2021. Tempeh: A semicentennial review on its health benefits, fermentation, safety, processing, sustainability, and affordability. Compr Rev Food Sci Food Saf. 20:1717-1767. doi: 10.1111/15414337.12710.

Barus T, Salim DP, Hartanti AT. 2019. Kualitas tempe menggunakan Rhizopus delemar TB 26 dan R.delemar TB 37 yang diisolasi dari inokulum tradisional tempe "daun waru". J Apl Teknol Pangan. 8 (4): 143-148. doi:10.17728/jatp. 2019.4449.

Boedijn KB. 1958. Notes on the Mucorales of Indonesia. Sydowia. 12 (1-6): 321-362.

Dolatabadi S, Walther G, Gerrits van de Ende AHG, de Hoog GS. (2013). Diversity and delimitation of Rhizopus microsporus. Fungal divers. doi: 10.1007/s13225-0130229-6.

Dung NTP, Rombouts FM, Nout MJR. 2005. Development of defined mixed-culture fungal fermentation starter granulate for controlled production of rice wine. Innov Food Sci Emerg Technol. 6 (4): 429-441. Doi:10.1016/j.ifset.2005.04.007.

Dung NTP, Phong HX. 2011. Application prospects for the innovation of defined fungal starter in rice wine fermentation. J Life Scie. 5 (4): 255-263. doi: 10.17265/1934-7391/2011.04.002.
Gallone et al. 2016. Domestication and divergence of Saccharomyces cerevisiae beer yeasts. Cell 166: 1397-1410. doi: 10.1016/j.cell.2016.08.020

Gallone B, Steensels J, Verstrepen KJ. 2020. Moulded by humans: The domestication of blue-veined cheese fungi. Mol Ecol. 29:2517-2520. doi: $10.1111 / \mathrm{mec} .15525$

Gibbons JG, Salichos L, Slot JC et al. 2012. The evolutionary imprint of domestication on genome variation and function of the filamentous fungus Aspergillus oryzae. Curr Biol. 22(15): 1403-1409. doi: 10.1016/j.cub.2012.05.033

Hartanti AT, Rahayu G, Hidayat I. 2015. Rhizopus species from fresh tempeh collected from several regions in Indonesia. Hayati J. Biosci. 22 (3): 136-142. doi: 10.1016/j.hjb.2015.10.004

Liu Q, Meng X, Li Y, Zhao C, Tang G, Li H. 2017. Antibacterial and anti-fungal activities of spices. Int J Mol Sci. 18 (6): 1283. doi:10.3390/ijms18061283

Maulana AI. 2019. Pembuatan tempe kedelai menggunakan Rhizopodopsis javensis sebagai starter alternatif [skripsi]. [Making soya tempeh using Rhizopodopsis javensis as alternative starter]. Bogor (ID): Insitut Pertanian Bogor.

Pramudito TE, Putri EGA, Paluphi E, Yogiara Y. 2021. The effect of starter culture on bacterial profile in soybean tempeh. Food Res 5 (1): 380 - 389. doi: $10.26656 /$ fr.2017.5(1).436

Rossi M, Buzzini P, Cordisco L, Amaretti A, Sala M, Raimondi S, Ponzoni C, Pagnoni UM, Matteuzzi D. 2009. Growth, lipid accumulation, and fatty acid composition in obligate psychrophilic, facultative psychrophilic, and mesophilic yeasts. FEMS Microbiol Ecol. 69 (3): 363-372. doi:10.1111/j.15746941.2009.00727.x

Santivarangkna C, Kulozik U, Foerst P. 2008. Inactivation mechanism of lactic acid starter cultures preserved by drying processes. J Appl Microbiol. 105 (1): 1-13. doi:10.1111/j.1365-2672.2008.03744.x

Seumahu CA, Suwanto A, Rusmana I and Solihin DD. 2013. Bacterial and fungal communities in tempeh as reveal by amplified ribosomal intergenic sequence analysis. Hayati J Bioscie. 20(2): 65-71. doi: 10.4308/hjb.20.2.65

[SNI] Standar Nasional Indonesia. 1992. Cara Uji Makanan dan Minuman (SNI 01-2891-1992) [ Test of food and beverage]. Jakarta (ID): Badan Standardisasi Indonesia.

Steensels J, Gallone B, Voordeckers K, Verstrepen KJ. 2019. Domestication of industrial microbes. Curr Biol. 29 (10): 381-393. doi:10.1016/j.cub.2019.04.025

Tahir A, Anwar M, Mubeen H, Raza S. 2018. Evaluation of physicochemical and nutritional contents in soybean 
fermented food tempeh by Rhizopus oligosporus. J Adv Biol Biotechnol 17(1): 1-9. doi: 10.9734/JABB/ 2018/26770.

Tamam B, Syah D, Suhartono MT, Kusuma WA, Tachibana S, and Lioe HN. 2019. Proteomic study of bioactive peptides from tempe. J Bioscie Bioeng 128 (2): 241-248. Doi: 10.1016/j.ijfoodmicro.2003.09.008.

Thanh NV, Nout MJR. 2002. Rhizopus oligosporus biomass, sporangiospores yield and viability as influenced by harvesting age and processing conditions. Food Microbiol. 19(1): 91-96. doi:10.1006/fmic.2001.0450.
Thanh, NV, Rombouts, FM, Nout MJR. 2007. Viability and physiological state transitions of Rhizopus oligosporus sporangiospores in tempe starter culture. Anton Leeuw Int JG 91(1): 35-44. doi: 10.1007/s10482-006-9093-7.

Wijaya CH, Nurjanah S, Utama QD. 2015. Implementasi dan analisis keuntungan teknologi Back-Slopping pada pembuatan "Quick Tempe" skala industri rumah tangga [Implementation and profit analysis using BackSlopping technology for "Quick Tempe" making at home industrial scale]. Pangan, 24 (1): 49-62. http://repository.ipb.ac.id/handle/123456789/75390. 